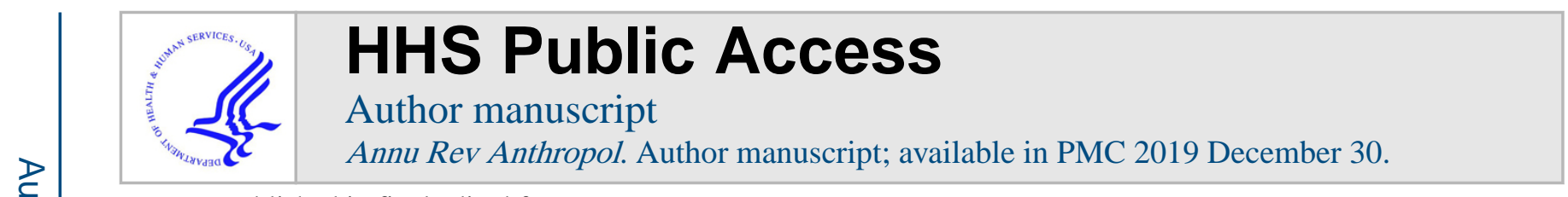

Published in final edited form as:

Annu Rev Anthropol. 2019 October ; 48: 133-150. doi:10.1146/annurev-anthro-102218-011346.

\title{
Environmental Politics of Reproduction
}

\author{
Martine Lappé ${ }^{1}$, Robbin Jeffries Hein ${ }^{2}$, Hannah Landecker ${ }^{3}$ \\ ${ }^{1}$ Department of Social Sciences, California Polytechnic State University, San Luis Obispo, San \\ Luis Obispo, California 93407-0329, USA; \\ ²Encino, California 91436, USA; \\ ${ }^{3}$ Department of Sociology and Institute for Society and Genetics, University of California, Los \\ Angeles, California 90095, USA;
}

\begin{abstract}
What constitutes "human reproduction" is under negotiation as its biology, social nature, and cultural valences are increasingly perceived as bound up in environmental issues. This review maps the growing overlap between formerly rather separate domains of reproductive politics and environmental politics, examining three interrelated areas. The first is the emergence of an intersectional environmental reproductive justice framework in activism and environmental health science. The second is the biomedical delineation of the environment of reproduction and development as an object of growing research and intervention, as well as the marking off of earlylife environments as an "exposed biology" consequential to the entire life span. Third is researchers' critical engagement with the reproductive subject of environmental politics and the lived experience of reproduction in environmentally dystopic times. Efforts to rethink the intersections of reproductive and environmental politics are found throughout these three areas.
\end{abstract}

\section{Keywords}

reproduction; environment; intersectionality; toxicity; developmental origins of health and disease; embodiment

\section{INTRODUCTION}

In 1991, "The Politics of Reproduction" by Ginsberg \& Rapp appeared in this journal. Reproduction, they wrote, was regarded as a "woman's topic" and understudied in anthropology, a situation changing with the "encounter between second-wave feminism" and the discipline (Ginsburg \& Rapp 1991, p. 312). The article was both a review and a call to action. It synthesized a somewhat scattered literature under one phrase, highlighting exciting areas of research such as stratified reproduction. It pinpointed understudied issues (fathering, care networks) and reclaimed subject matter treated previously as proper only to quantitative scientific approaches, recognizing that demography and biomedicine are themselves political, cultural endeavors. It pushed readers to see social reproduction in biological

mlapp@calpoly.edu. 
reproduction across areas of inquiry from reproductive technologies to breastfeeding and became a call to scholarship still being answered to this day (Schiavenato \& Rapp 2018).

Stratified reproduction: the differential valuation of biological and social reproductive labor, care work, and autonomy in different socioeconomic and national contexts, and the resulting patterns of inequality and commodification of reproductive labor.

We honor this work by showcasing a growing overlap between the politics of reproduction and hitherto rather separate environmental politics. What has changed in the intervening years? Subsequent generations and different constituencies of "ethnographers of late industrialism" have entered the scholarly domain fostered in the 1990s, living through pregnancy, changing family formations, LGBTQ+ (lesbian, gay, bisexual, transgender, queer, and others) activism, infertility, and disability in a postgenomic and politically fraught chemical landscape of extinction, pharmaceutical proliferation, antibiotic resistance, food adulterants, and compromised air and water (Fortun 2012). Feminist frameworks of intersectionality in the literature on gender and climate change mobilize environmental and reproductive politics, while growing scientific and public awareness of environmental inequalities consequential to reproductive health gives the "political ecology of procreative labor" new reach (Ivry 2015, p. 274, Kaijser \& Kronsell 2014). Persistent pollutants, while by no means new, are now more widely recognized under the general moniker of the Anthropocene, and environmental responsibility, stewardship, extraction, and monitoring are central to the present biopolitical moment (Murphy 2011).

The very constitution of "human reproduction" is under negotiation in anthropology and beyond because its biology, social nature, and cultural valences are increasingly perceived as bound up in environmental issues. These entwined politics are visible, for example, in the declaration from Standing Rock that "environmental justice is reproductive justice" during protest of pipeline construction (Lorenzo 2016). Or, consider the imbrications of reproduction and environment in pandemics such as Zika, an issue of reproductive consequence and governance of both women and mosquitoes, encompassing domestic animals, insects, climate change, and anthropogenic ecosystems (Fauci \& Morens 2016, Johnson 2017).

We do not seek to address every meeting point of environments and reproduction, but to examine how reproductive and environmental politics overlap, clash, and mutually transform today. These conjunctures are many and necessarily include critical literature on the very question of "reprocentricity" in environmental discourse (Butler 2017). Alongside environmental reproductive issues such as endocrine disruptors come an inescapable politics of representation that is both an empirical object and a challenge to analysis. As AgardJones puts it, ethnographers face the challenge of taking informants' anxieties about such issues "seriously while refusing a retrenchment into fantasies about 'normal' bodies" or individualized narratives of responsibility (Agard-Jones 2013, p. 190). Scholars are generating new vocabularies around "politics of habitability" or "politics of survival," reconfiguring questions of what is at stake for whom (Langwick 2018, Maxwell 2017). It is not that all distinction disappears and reproduction is now about everything. One can remain centered by questions of human reproduction and its cultural forms, yet observe that 
empirical research in this area is changing in relation to environmental events and politics, accompanied by critical debates around antinatality and heteronormativity in environmental discourse (Clarke \& Haraway 2018, Pollock 2016).

Antinatality: holds procreation to be morally problematic as not-yet-born individuals cannot consent to existence, and will likely suffer, harm others, drain resources, and generate anthropogenic environmental degradation.

Anthropology has long analyzed human reproduction in ecological and evolutionary terms (Voland 1998). Yet sciences of anthropogenic change are never neutral in contests over resources and representation; human ecology has its own imperial history of colonialism and population management (Anker 2001). In addition, the relevant ecologies are formatted by social, cultural, economic, and technological forces. Climate-related food insecurity, air pollution, deforestation, and radiation fallout create environments that are unequally hazardous, resource rich, or multiply impacted, just as societies are (Sze 2006). The exercise of economic, military, or political power results in a geography of differential exposures to physical and social stressors, from depleted uranium to racism, that shape reproductive outcomes and possibilities, manifesting, for example, as differential reproductive health impacts or maternal and child mortality (Davis 2019, Dewachi 2015, Djoudi et al. 2016). Biological and ecological approaches are essential to understanding this landscape, but our focus in this review is on the political nature of life as embodiment in unequal environments, and the question of who is left to take responsibility for what then unfolds. ${ }^{1}$

These environmental politics of life are not necessarily specific to human reproduction. Indeed, much of the literature in anthropology about the Anthropocene, climate change, microbiomes, chemo-ethnography, citizen science, or environmental politics lists reproduction as one concern among others, if at all (Kirksey \& Helmreich 2010, Sayre 2012, Wylie et al. 2017). Yet the specific intersections of reproductive and environmental politics merit their own focused consideration, and the contours of "reproducing the environment" are shaping much new work in anthropology (Dow \& Lamoreaux 2019). We have organized this review around three interrelated nodes of relevant literature: the emergence of an environmental reproductive justice (ERJ) framework, the technical and scientific delineation of the environment of reproduction as an object of study and intervention, and the reproductive subject of environmental politics.

\section{FROM REPRODUCTIVE RIGHTS TO ENVIRONMENTAL REPRODUCTIVE JUSTICE}

Environmental justice (EJ) has long highlighted how social inequalities and power differentials shape human environments and health outcomes, from Bhopal to Flint, influencing anthropological inquiry in both empirical and theoretical directions (Fortun 2009). Reproductive politics framed around reproductive rights have shifted toward RJ

\footnotetext{
${ }^{1}$ Embodiment is a long-standing theme in anthropology; the phrase "embodiment in unequal environments" is meant to highlight that inequality of environments (in physical and social hazards, enrichments, or stressors) might structure the processes of embodiment itself, as well as its consequences. Thanks go to Hannah Appel for her contribution to conceptualizing the idea in the form of a seminar series by the same name held at the University of California Los Angeles in the spring of 2016.
} 
thanks to a broadening of the constituency speaking to these matters, in particular indigenous scholars and activists for whom climate justice, multispecies environmental awareness, and reproductive advocacy are not, and have not been, separate domains (Hoover et al. 2012, TallBear 2011, Whyte 2016).

\subsection{Reproductive Rights, Reproductive Justice, Environmental Justice}

The concept of reproductive rights reflects a philosophy of individualism where reproductive choice and legal privacy denote a right to terminate a pregnancy as well as control over contraception, i.e., the right to not have children (Gaard 2010, Luna \& Luker 2013). By contrast, a framework of RJ emerging from human rights and women of color feminism in the 1990s, e.g., the SisterSong Women of Color Reproductive Justice Collective, emphasizes an intersectional methodology to illustrate the effects of class-, race-, gender-, sexuality-, and disability-based discrimination on reproductive lives (Crenshaw 1989, 1991; Ross \& Solinger 2017). The RJ framework recasts definitions of choice to mean the right to conceive, bear, and raise children in positive "conditions of social justice and human flourishing for all," regardless of social location (Luna \& Luker 2013, p. 328). Here, the right to reproductive health for individuals, families, and communities and the right for people to make informed decisions about their "bodies, sexuality, and reproduction" are central (Asian Communities Reprod. Justice 2005).

The concept of EJ formally appeared in the United States in the early 1990s among activists as an outgrowth of environmental advocacy coalescing around political objectives of the 1960s civil rights movement. Earlier twentieth-century mainstream environmentalism viewed nature as pure, wild, and in need of protection from human encroachments (Catton \& Dunlap 1978, Roberts 2016, Taylor 2000). The nascent EJ movement of the 1960s, however, emphasized relational interdependence of hazardous environmental conditions (nature) and human health (society) specifically in terms of the disproportionate impact of environmental toxicants on communities of color (Bullard 1993). Today, many of the same concerns around the "simultaneity of oppression" (Taylor 2000, p. 523) are found not only among the most politically vulnerable in the United States but also within indigenous rights movements globally (Dove 2006, Hoover et al. 2012, Little 1999, Singer 2016).

\subsection{Intersectionality as Activism; Intersectionality as Method}

In interviews with "advocates working to protect communities of color, Indigenous, and low-income communities from toxicants harmful to reproductive health," Mandell and colleagues (2018) found that intersectionality functioned as a "master" collective action frame, allowing connections across issues, identities, and movements that otherwise were regarded as relatively "siloed" into separate EJ or RJ boxes (p. 348). An intersectional heuristic also shapes environmental health research in conversation with advocacy, situating reproductive practices and outcomes within multiple contexts from chemical exposures in homes and workplaces (Morello-Frosch \& Shenassa 2006, Richardson 2006) to impacts of climate change on social organization of family and work life (Terry 2009).

Intersectionality therefore occupies an interesting multilayered role as social, empirical, and theoretical conduit between previously separate topics or constituencies. Its use counters 
tendencies for terminology such as the "Anthropocene" to homogenize environmental phenomena. MacGregor (2010) argues that women and girls are disproportionately affected both physically (sexualized violence) and socially (as wives, caregivers, family provisioners) by climate change, yet the dominant narrative depicts "a human crisis in which gender has no relevance" (Kuehn \& McCormick 2017 p. 225). The intersections of gender and climate change are a methodological prompt for studying structural forces shaping reproductive outcomes; for example, rising water salinity has the most impact on those who cannot afford to move or remediate, leading to differential hypertension and miscarriage rates in Bangladeshi shoreline communities (Vineis et al. 2011).

For EJ theorist di Chiro (2008), "All environmental issues are reproductive issues... [because] environmental struggles are about fighting for and ensuring social reproduction" (p. 285). Yet enormous heterogeneity characterizes environmental reproductive advocacy and science. Sciences of exposure have been buoyed by "embodied health movements," collective organizing, and citizen science (Brown et al. 2004, Shostak 2013). Individuals and communities may leverage their experiences to provide data and samples, but also to challenge biomedical framings of diseases, including reproductive cancers and developmental delays (Eskenazi et al. 2008, McCormick et al. 2003). These efforts have helped position environmental health as central to larger research endeavors and positioned people's lived experiences as foundational to social movements related to "contested illnesses" (Barker 2005, Brown et al. 2012). Nonetheless, community cohesion around a shared threat to biological and social reproduction is not an inevitable outcome, particularly in resource-poor settings (Auyero \& Swistun 2009).

\subsection{Environmental Reproductive Justice}

Hoover delineates the emergence of "environmental reproductive politics" in the context of ethnography in the Mohawk community of Akwesasne (Hoover 2017, 2018). More than sheer coincidence or rhetorical strategy drives alignment of EJ and RJ aims, here and elsewhere. The materiality of historical change and the socioeconomic and racial stratification of distribution of industrial waste and food mean that reproductive systems and developing organisms are impacted in distinctive ways. Chemicals mass-produced in the twentieth century were designed to be neurotoxic, lipophilic, membrane piercing, or longlasting; it was part of their design to mimic hormones, to interact with air or water in particular ways, or to participate in specific physiological processes; they were regulated to be there. Reproduction and development have thereby been uniquely enrolled in economic projects that entail disposing waste at least cost, which often meant dumping in low-income, marginalized communities (Liboiron 2013).

For Hoover and her interlocutor Katsi Cook, a Mohawk midwife who first articulated the concept of environmental reproductive politics, this material conjuncture of environmental and reproductive harms exceeds the sum of its parts. Shifting the valences of "reproductive" in RJ is part of the concept. Disrupted foodways and traditions are part of the material legacies communities live with, and the reproduction of language and culture are as much concerns as are the physical reproduction of human beings in this setting. If the Anthropocene is understood as beginning in 1610 with the colonization of the Americas, and 
the settler colonialist "severing of relations between humans and the soil, between plants and animals, between minerals and our bones," then environmental reproductive justice is a simultaneously theoretical and practical attempt to care for a set of relations and reclaim reproduction in decolonized terms (Davis \& Todd 2017, p. 770).

Environmental reproductive justice is a key site of environmental politics of reproduction, as previously separate concerns about individual rights and environmental purity change and connect via concepts of justice. An environmental reproductive justice perspective involves more than the right to not have children and the right to parent children with dignity; the antigenocidal spirit in which it is mobilized moves the debate from individual bodies to cultural collectives, as it pushes EJ to more closely consider the impacts of pollutants on both physical and cultural reproduction and pushes RJ to consider the environment more deeply (Hoover 2018).

\section{EMBODIMENT IN UNEQUAL ENVIRONMENTS: THE "EXPOSED BIOLOGIES” OF REPRODUCTION}

The environments of reproduction have come to matter more, are more legible, and are more fraught in anthropologists' fieldsites. Why now? It has been decades since fights over lead centered on its cognitive developmental effects, an ongoing concern (Fennell 2016, Graeter 2017, Muller et al. 2018). Recognition of DDT (dichlorodiphenyltrichloroethane) as a reproductive toxicant was formative for the environmental movement after Silent Spring (Carson 1952). And as the work reviewed above powerfully reminds us, interlinked destruction of environments and peoples has deep historical roots. Thus, it is not that pollutants or the scale of their impacts is new, nor is environmental politics configured by reproductive concerns novel. Yet the physical and social environments of reproduction are nonetheless becoming different kinds of object and subjects of advocacy, intervention, protest, investment, and responsibility. Understanding the historical specificity of our time lies in the advocacy framework outlined above and in convergent biomedical and policy developments that foreground environments of conception, pregnancy, and development as both unique and significant to the entire life span (Lappé \& Landecker 2015).

This research shapes policy initiatives directed at reproductive-age populations, pregnant women, infants, and children. It shapes the public health discourse around reproductive cancers and sexual health, enfolding questions of diverse bodies-not just ones that bear children-in the environments of reproduction and development. From the making of mothers into environments for fetuses to the highlighting of the socioeconomic forces shaping the chemical milieu of early life of all future adults, these knowledge regimes are reshaping the politics of the life course (Lappé 2016a). We now turn to biomedical registers through which environments of reproduction are made into distinctive objects of study and domains of potential intervention, and the anthropological study of them.

\subsection{Child Environmental Health and Developmental Origins of Health and Disease}

It might seem obvious that "children are not little adults," as the 1993 report Pesticides in the Diets of Infants and Children famously put it, but much work went into making it 
possible to understand reproductive and developmental biologies as processes uniquely sensitive to environmental inputs, often called critical or sensitive windows of development (Natl. Res. Counc. 1993). One can argue that the toxic landscape of World War II and postwar chemical and pharmaceutical production made the environments of conception, pregnancy, and child development uniquely visible as sites of biological vulnerability by causing harms unique to certain life stages. Microcephaly in infants and leukemia in children exposed to bomb blasts in Hiroshima and Nagasaki showed radiation's differential effects; radioactive fallout anxieties spurred the American Academy of Pediatrics to establish a committee on Radiation Hazards and Epidemiology of Malformations (Landrigan 2016). This response nucleated a focus on children's environmental health in the wake of thalidomide, diethylstilbestrol (DES), and lead, with their distinct harms to fetuses and children (Goldman et al. 2004). In turn, DES was central to coining the term endocrine disruptor to encompass a class of chemicals with unique impacts on reproductive physiology, cancers of the reproductive system over the life course, and infertility (Colborn et al. 1993).

Ideas of critical windows of development also have eugenic roots. Progressive-era concerns about racial degeneration of alcohol-exposed germlines spurred use of the first animal models for testing environmental exposures in relation to fertility and in utero development (Pauly 1996). This parent-to-child hereditary axis of concern was supplemented in the landscape of war by a focus on the life course, specifically social conditions of nutrition as formative environments in interwar and post-World War II Britain (Buklijas 2014). Epidemiological studies in the 1980s linked nutrition in pregnancy and birth weights to risk of cardiovascular disease late in life (Barker \& Osmond 1986). As with radiation, war was central; cohorts of individuals in utero during the 1945 Dutch Hunger Winter were key in supporting the Barker hypothesis of long-term impacts of early nutrition. Food was thereby reconceptualized as one form of biologically meaningful exposure among others (Landecker 2011). Throughout the twentieth century, an assumption of the causal primacy of maternal environments in fetal growth profoundly shaped study design and interpretation of findings (Sharp et. al. 2018). -

Today, the developmental origins of health and disease $(\mathrm{DOHaD})$ concept is important in public environmental health research and biocultural anthropology (Heindel et al. 2016). The field has shifted in focus from nutritional determinants to environmental factors as diverse as psychosocial environments, microbial cues, and toxicants in early life (McDade 2012, Mulligan 2016). Molecular causal chains identified by environmental epigenetics after 2000 provide gene regulatory and physiological explanations that bolster epidemiological correlations. Ontological flattening of differences between physical components of environments (nutrients, toxicants) and social ones (stress, parenting behavior, violence) allows the articulation of powerful models for intergenerational transmission of multidimensional environmental inequalities embodied via epigenetic imprinting (Kuzawa \& Sweet 2008, Landecker \& Panofsky 2013). Such biosocial frameworks have invited new modes of communication among cultural, medical, and biological anthropology (Thayer \& Non 2015). 
Developmental origins of health and disease (DOHaD): multidisciplinary research field studying how early environments interacting with genotypic variation shape disease risk, aging, and resiliency in later life.

At this juncture we should underscore that the advocacy frameworks laid out above shape the knowledge production in biomedicine and public health described here, just as these knowledge discourses provide a vocabulary for what is at stake in environmental reproductive health inequalities; there is mutual influence, even with vast difference in social power and access to resources and policymaking. For example, the International Federation of Gynecology and Obstetrics' "opinion on reproductive health impacts of exposure to toxic environmental chemicals" was endorsed by a wide range of professional societies representing physicians, midwives, and nurses (di Renzo et al. 2015). It underlines unequal distribution of chemical exposures globally across ethnic and socioeconomic lines. And the report calls for shifts in practice (recognizing differential burdens of toxicity borne by different patients and including environmental health advice in consultations) and for professionals to "advocate for policies to prevent exposure to toxic environmental chemicals, work to ensure a healthy food system for all, make environmental health part of health care, and champion environmental justice" (di Renzo et al. 2015, p. 219).

\subsection{Ethnography of "Exposed Biologies" and the Politics of Early Life}

Salience and contestation of environments of reproduction are visible in a literature that can be characterized as the ethnography of "exposed biologies" (Wahlberg 2018). Nuclear weapon use and testing and catastrophes at nuclear plants such as Chernobyl and Fukushima have left "life exposed" (Petryna 2002). Petryna's work in Ukraine and Masco's analysis of the "mutant ecologies" of the southwestern United States both captured the entwinement of state politics, political economy, a sense of the future, and biological harms in studies of lives (of humans and nonhumans) under conditions of exposure (Masco 2004). Further studies underscore the long-term impact of war on environments of reproduction, for example in legacies of Agent Orange (Gammeltoft 2014, Reagan 2016).

Widespread industrial pollution of the air, water, and food supply has meant that "exposed biologies have become a matter of concern" in countries around the world, reframing infertility in China as an ecological problem not an individual one and contributing to the emergence of sperm banking (Lamoreaux 2016; Wahlberg 2018, p. 78). Early-life exposure is both a national issue and an international one. Mobilization of reproductive biologies as particularly vulnerable, and as sites of latency for chronic diseases, is evident from obesity prevention in Guatemala to child malnutrition studies in Bangladesh that are mining the microbiome for potential explanations and "early interventions" (Benezra 2016, Yates-Doerr 2015). The transnational First 1000 Days campaign endorsed by the World Health Organization (WHO), the United Nations, and nongovernmental organizations and private philanthropies focuses squarely on pregnancy and early life as vital for later health (Pentecost 2018).

The trope of investment-in future generations, in girls-is apparent in the merger of economic models of human potential with epigenetic logics of critical periods, with environmental compromise translating into lost learning and earning potential (Currie et al. 
2014). This economization of life is manifest in campaigns against air pollution, for example in the 2017 WHO report Don't Pollute My Future! The Impact of the Environment on Children's Health (Murphy 2017b, WHO 2017). Investment on the global stage includes negotiating international collaboration between birth cohort studies in a reach for statistical significance in studying the population effects of mass exposures. Thus the very ground of evidence making is under construction, enrolling ever more people into longitudinal birth cohort studies and producing different kinds of study subjects, those whose life courses are repeatedly sampled, rather than one-off blood draws or survey responses, and who are actively engaged over the long term as community partners and targets of health literacy efforts (Lappé 2014). ${ }^{2}$ Statistical risk assessments developed from such populations form the future conditions for action on reproductive environments by governments or individuals, as we discuss below.

Longitudinal birth cohort study: clinical assessment and biological sampling from people born in the same period or year over years or decades, often collecting data on variables such as exposure to pesticides or air pollution.

A thoroughly equivocal relationship can be seen in the ways anthropological scholarship has taken on these biomedical and public health developments, an obligatory paradox of "working with and against technoscience" (Murphy 2017a, p. 495; Yates-Doerr 2019). The work of social scientists documenting exposures and mapping the social landscape of proximity to industrial sources of toxicants and unequal remediation resources gives empirical depth to the "riskscape" of reproductive health inequality (Morello-Frosch et al. 2001). Participatory research designs have focused on the reproductive and developmental legacy of polychlorinated bisphenols (PCBs) in Mohawk communities, with coauthorship and community collaboration central to the project (Gallo et al. 2018). Biocultural anthropologists are reconsidering the maternal environment as a complex intergenerational set of "physiological, social, and political-economic processes" rather than as something that emerges in each body de novo (Hoke \& McDade 2014, p. 191).

At the same time, documentation of harms-particularly in the absence of action-can wreak its own damage, foreclosing other ways of knowing: "[T]he pursuit of science in these instances has the potential to foreclose imaginative horizons of 'how' and 'why' in favor of 'how much"' (Shapiro et al. 2017, p. 575). Interventions focused primarily on the nutritive or care environment of fetuses and infants can exclude broader social framings of the conditions of early life and foreclose women-centered approaches (Colom 2015, Pentecost 2018). Data can return to communities in unwanted ways and go on to be used in ways that its originators never anticipated or to which they never consented (Radin 2017). Any model of health carries normative assumptions about bodies, control, and families, from assumptions about healthy body size implicit in narratives of (mal)nutrition in early life to "normal" sexual and neurological development (Mansfield \& Guthman 2015).

\footnotetext{
${ }^{2}$ A panel at the 2019 American Anthropological Association annual meeting entitled "Birth Cohorts, Anthropology, and Biosocial Research" organized by Sahra Gibbon showcased new work in this area.
} 
In sum, chemistry, public health, and biomedicine play a central role in the environmental politics of reproduction both in the design and distribution of environment-altering materials in the first place and, recursively, in the production of a technical vocabulary for evidence of harm. They bring effects of former interventions into view with the tools of epidemiology, body burden monitoring, and use experimental systems to give molecular causal narratives to life experiences. Findings from such studies in turn reconfigure experience of the environment as molecularized, polluted, and biologically potent. New understandings of bodies and personhood-exposed, empowered, compromised, neurodevelopmental, epigenetic - and new forms of reproductive labor, under new forms of surveillance and exclusion, are part of the scientific and policy worlds of environmental reproductive health.

\section{LIVING IN ENVIRONMENTALLY DYSTOPIC TIMES: THE REPRODUCTIVE SUBJECT OF ENVIRONMENTAL POLITICS}

Authors and purveyors of biomedical explanations, statistics, activist efforts, and policy changes frame the world in very particular ways. However, what is understood as an "environmental factor" by an epidemiologist might look like the contours of expressing love in the everyday life of a family; what it means to pathologize that factor is very different to the various participants in discourses of health (Roberts 2015). Information about environmental exposures and developmental resources in the form of pollutants, diet, stress, trauma, and care now circulates widely across public health interventions, driving messages of "responsible" family planning, "safe" pregnancy, and "good" parenting. This discourse shapes new political subjects and forms of personhood and community, and influences lived experiences of reproduction. Anthropologists are uniquely situated to understand these different facets of cultural change and lived experience, work to which we now turn.

\subsection{The Reproductive Subject of Environmental Health Discourse and Research}

Within a larger set of ethnographic engagements with life exposed, a smaller subset is concerned principally with reproductive life exposed. The impossibility of defining which ethnographies concern reproductive environments and which do not shows that even when early-life or reproductive health is singled out as particularly determinative or impacted in any given setting, people do not experience them in isolation from other aspects of life. As the environmental reproductive justice framework emphasizes, biological and cultural reproduction must be thought through together. Graeter's work on the politics of lead exposures around mines in Peru, for example, demonstrates that community concerns about compromised development in children, and fear about the effects of cancer and respiratory disease on the ability of adults to care and provide for themselves and their families through gardening or work, are part of a continuous experience of what is at stake in protest (Graeter 2017). Moran-Thomas, working in Belize, shows how visible environmental degradation of coral reefs and beaches shapes her interlocutors' sense of diabetes inside their bodies, as well as changes over human generations (Moran-Thomas 2019).

These are quite different settings and analyses, but each observes local experiences of grappling with pervasive chemicals as elements of economic infrastructures, with individuals participating in a wide range of narrative and sense-making practices for those 
experiences. Discourses of environmental reproductive harm come from science and public health, as discussed above, but they may also be present in rumor, advertising, propaganda, and advice networks, as well as in the embodied feeling of being a body in space in these particular places over time. Agard-Jones (2013) analyzes the experience of endocrine disruptor exposure in the Caribbean by pointing to bodies as "small places" where larger systems of power manifest, reading in her interlocutors' embodied experiences connections to "commodity chains, to uneven relations of colonial/postcolonial power, and thus to world systems" (p. 190). Sometimes the experience is of "toxic uncertainty," particularly in situations where people do not have the means to move or ameliorate the systemic impacts borne by individual bodies (Auyero \& Swistun 2007).

Participating directly in environmental reproductive health research as a study subject is an increasingly common experience as cohorts grow to meet demands for statistical significance and large sample collections. Roberts uses "bio-ethnographic" methods to engage with the experiences of such knowledge production at multiple levels: by living in the neighborhoods with families in the Early Life Exposures in Mexico to Environmental Toxicants (ELEMENT) cohort and using ethnographic methods to complicate the measures and findings of that study (Roberts \& Sanz 2018). The experiences of participants are in themselves a site of inquiry, but participant engagement can also reposition scientific concerns about water safety, diet, early menarche, and adolescent pregnancy within complex social and political histories that challenge individualistic accounts that may result from the science alone.

Elsewhere, Valdez (2018) studies DOHaD clinical trials in the United States and the United Kingdom as ethnographic sites where claims about nutrition, pregnancy, and obesity are coproduced. She finds that this science opens up multiple ways of knowing "the environment," while nevertheless individualizing responsibility onto pregnant bodies. Women experience messages about the potential impacts of environmental exposures as individual responsibilities that they must actively negotiate, as in preconception health campaigns that position women's bodies as sites for future reproduction, and autism research studies that rely on pregnant women's participation to advance understandings of environmental factors in child development (Lappé 2016b, Waggoner 2017).

As "embedded bodies" (Niewöhner 2011), and sites of potential contamination (Mansfield 2017, Washburn 2014), women's bodies have thus become concentrated sites ("vectors" and "smoking guns") through which epigenetic and DOHaD claims about the reproductive effects of environmental conditions are increasingly made (Richardson 2015, Warin et al. 2012). Although more literature on male fertility and men's experiences of reproduction and environmental risk is now appearing, the reproductive subject remains primarily female (Almeling \& Waggoner 2013, Daniels 2006).

\subsection{Environmental Reproductive Responsibility}

The paradoxical twinning of vulnerability and responsibility encapsulated in the literature above points to a widespread pattern: individualization of collective problems. This tendency is repeated when population growth as environmental threat is tied to women's control of fertility, producing a simultaneously vulnerable and empowered subject that Sasser (2018) 
terms a "sexual steward" of the environment. Clarke and Haraway enjoin us all to "make kin" rather than babies through this linkage of population and environmental destruction; while they decry the coercive and violent pasts of birth and population control, Sasser's trenchant critique of such dispositions of responsibility remains pertinent (Clarke \& Haraway 2018, Haraway 2015). This debate illustrates how ideas of livable worlds are changing with increasingly catastrophic narratives of environmental change, impacting the sense of responsibility individuals may feel to future humans-but there is no guarantee of shared agreement about what that responsibility is or what forms it should take (Dow 2016b).

Whether in environmental population politics writ large or environmental reproductive health politics writ small, the experiences of being the person depicted as centrally responsible via one's body and choices for children and future generations may be found in many settings (MacKendrick 2014). Burgeoning scientific study of the reproductive and maternal-infant microbiome has the potential to highlight infrastructural and societal drivers and impacts of caesarean section, undernutrition, antibiotic use, and breastfeeding practices, which could point to social responsibilities for microbial health in terms of prenatal care and parental leave policies (Aagaard \& Segars 2014). At the same time, new narratives such as the hygiene hypothesis (linking autoimmune conditions to excessive cleanliness in early life) extend caregivers' responsibilities beyond the family to its microbes as well (Hodgetts et al. 2018). At stake in the sciences that shape our understandings of the environmental politics of reproduction then are also the responsibilities they may help produce (Altman et al. 2008).

For example, MacKendrick \& Cairns show how “the frame of children's health—from fragile fetus to vulnerable child-increases public resonance of the urgency of environmental pollution," as reflected in stronger regulation of bisphenol A and flameretardant chemicals in the United States (MacKendrick \& Cairns 2019, p. 310, Cordner 2019, Lubitow 2013). In this context, however, environmental health movements may place blame for environmental harms with the government but often position the responsibility to protect children on individuals. This leads women in particular to enact good motherhood through practices of "precautionary consumption": buying products to protect themselves and their families in the face of government inaction (MacKendrick 2018).

At the same time, epigenetics has been taken up in some ways as a useful resource for affirming in another register what was already known in indigenous communities about intergenerational transmission of effects of dispossession, colonization, and trauma (Kowal $\&$ Warin 2018). Sciences do not, in themselves, determine what is done with them. Frequently gendered and racialized responsibilities associated with emerging sciences are new valences to longer trajectories that position women and minority communities as vectors of fetal risk (Kenney \& Müller 2017). Epigenetics or the microbiome should not be granted unwarranted agency as the source of changes in perspective on bodies and environments and their interrelation; however, their mobilization as resources and burdens may be analyzed as manifestations of the larger unfolding scene of environmental politics of reproduction. 


\section{CONCLUSION: RETHINKING REPRODUCTION AT THE NEXUS OF REPRODUCTIVE AND ENVIRONMENTAL POLITICS}

The environmental politics of reproduction is an intensifying zone of contestation, advocacy, medicalization, pollution, monitoring, moralizing, intervention, and care. By describing it, we do not mean to imply that more classic issues such as stratified caregiving labor, reproductive autonomy, and in vitro fertilization — or more recent topics such as surrogacy, embryonic stem cells, or emergency contraception—have lost any urgency. Yet these will also shift with the scene of environmental politics of reproduction described here. We have reviewed literatures generated at the conjuncture of RJ and EJ, reproductive developmental biology and the environmental legacies of war and industry, reproductive health policy and the socioeconomic stratification of nutritive and toxic environments, and the lived experience of environmental reproductive politics. The domains covered by the terms environment, reproduction, and politics are themselves in flux, and we end by discussing theoretical and methodological directions by which future anthropology of the environmental politics of reproduction might be guided.

The thinking together of reproduction and infrastructure is one such guide, for example in the concept of "distributed reproduction" put forward by Murphy (2011) in an effort to grasp the long temporal effects of chemical infrastructures. Murphy (2013, p. 1) asks, "[I]f in studying reproduction and participating in reproductive politics, one aims not just to reproduce the same," then what opportunities do these crossing points of ecological heuristics, environmental politics, and reproductive issues present for different theoretical insights and new methodological orientations? One answer is a framework that sees questions of reproduction in infrastructures rather than only in the body in pregnancy, birth, or infancy: "state, military, chemical, ecological, agricultural, economic, architectural - that 'assist,' alter, rearrange, foreclose, harm, and participate in the process of creating, maintaining, averting, and transforming life in intergenerational time" (Murphy 2013, p. 2). Literature on the politics of infrastructures (Larkin 2013), the anthropogenic (Sayre 2012), and potentiality (Taussig et al. 2013) can all be brought to bear on the study of reproduction that does not end at the skin.

Methodologically speaking, such approaches pose challenges to arenas previously dominated by literature on bodies and embodiment, in terms of knowing where to look and what to follow empirically in order to track distributed reproduction as it unfolds, is contested, is regulated, and is lived (Lock 2018). It is not just that the environment can be embodied but that embodiment itself is processual and relational. The material and social environment can materially shape the possibilities for embodiment, from food to placental biology or gut integrity; it can impact the social form of communities and thereby the "porosity" of both bodies and communities (Roberts 2017).

Rethinking reproduction as multispecies is a second burgeoning area. Indigenous scholars lead the way in articulating environmental reproductive justice situated in diverse kinship ontologies that include not just other species of plants or animals, but also nonhuman entities, for example water as a living being (Hoover 2017, Wilson \& Inkster 2018). Microbiome and ecological science provides new layers to birth narratives, depicting the 
process of one community giving rise to another, communities which then develop commensally (Gilbert 2014). In this light, human reproduction "reproduces whole communities of nonhumans" because "human bodies are a seething site of multispecies kinship networks" that are transferred "as soon as the next body emerges from the first" (Fuentes \& Porter 2018). Scholarly attention to reproduction as multitudinously multispecies is providing new empirical openings on infertility, childhood allergies, and resilience to environmental toxicants in biomedicine and thus is poised to further shift narratives of birth and kinship (Cortese et al. 2016, Franasiak \& Scott 2015).

Whether cloning endangered animals or attempting to eradicate invasive species and "pests," humans constantly intervene in the reproduction of other species, often in an effort to counteract previous anthropogenic impacts (Friese \& Marris 2014). Animals figure as sentinels for the reproductive risks of endocrine disruptors and as models for their in utero effects in experimental settings (Jeffries Hein 2018). The recent spread of colony collapse disorder in bees, which are central to the pollination of food crops, underlines the interdependence of humans and many other species (Suryanarayanan \& Kleinman 2016). The multispecies perspective is not exclusive of an infrastructural approach: These are empirical questions of biotechnological, animal, plant, insect, and microbial infrastructures, particularly economically important agricultural and tourism infrastructures.

Finally, this literature is rife with opportunity and imperative to rethink reproduction in environmentalism, Anthropocene and extinction narratives, environmental health sciences, and ethnography (Dow 2016a). A rash of contributions attempting to formulate new ethical and political concepts at the intersection of environment and reproduction signals a widespread desire to develop new vocabularies and reproduce different futures. These include, for example, a "politics of habitability," as Langwick (2018) puts it in her study of Tanzanian homeopathic plant cultivation practices, with close attention to "whose ongoingness and what forms of continuance" are supported in multispecies reproductive practices (p. 436). Maxwell, in articulating an "alternate politics of survival in the face of climate change," rereads Silent Spring through the lens of love letters between Rachel Carson and Dorothy Freeman, arguing that the threat of pesticides is a threat not just to "mere life," but to love cultivated through relationship to birds (Maxwell 2017, p. 682). Sterility in Silent Spring is referring not to the loss of human reproduction, but to the loss of myriad organisms and the density of human/nonhuman interrelation in the name of technological progress and comfort. A "politics of toxicity" has been proposed to draw attention away from "molecules behaving badly" and toward struggles over which forms of power allow and disallow life (Liboiron et al. 2018). What characterizes these new approaches is an effort to analyze questions of environment and reproduction as ones of habitability, persistence, and survival, for multiple lives at multiple scales.

\section{ACKNOWLEDGMENTS}

We thank Katie Dow, Janelle Lamoreaux, Anne LeGoff, Elizabeth Roberts, and Emily Yates-Doerr for their assistance and generosity in reading an earlier draft of the manuscript and suggesting sources. All errors remain our own.

DISCLOSURE STATEMENT

Annu Rev Anthropol. Author manuscript; available in PMC 2019 December 30. 
Work on this article was funded in part by the following grants: National Human Genome Research Institute (NHGRI) project number R00HG009154-03, "Behavioral Epigenetics in Children: Exploring the Social and Ethical Implications of Translation" (M.L.), and John Templeton Foundation project number 60742, "A Chance to Equality in Health: Is People's Health Determined by Ancestral Environmental Exposures?" (H.L.).

\section{LITERATURE CITED}

Aagaard KM, Segars JH. 2014 What is the microbiome and how do we study it? Semin. Reprod. Med 32:3-4 [PubMed: 24390914]

Agard-Jones V 2013 Bodies in the system. Small Axe 17:182-92

Almeling R, Waggoner MR. 2013 More and less than equal: how men factor in the reproductive equation. Gender Soc 27(6):821-42

Altman RG, Morello-Frosch R, Brody JG, Rudel R, Brown P, Averick M. 2008 Pollution comes home and gets personal: women's experience of household chemical exposure. J. Health Soc. Behav 49(4):417-35 [PubMed: 19181047]

Anker P 2001 Imperial Ecology: Environmental Order in the British Empire, 1895-1945 Cambridge, MA: Harvard Univ. Press

Asian Communities Reprod. Justice. 2005 A new vision for advancing our movement for reproductive health, reproductive rights, and reproductive justice. Rep., Asian Communities Reprod Justice, Oakland, CA https://forwardtogether.org/wp-content/uploads/2017/12/ACRJ-A-New-Vision.pdf

Auyero J, Swistun D. 2007 Confused because exposed: towards an ethnography of environmental suffering. Ethnography 8(2):123-44

Auyero J, Swistun DA. 2009 Flammable: Environmental Suffering in an Argentine Shantytown New York: Oxford Univ. Press

Barker DJ, Osmond C. 1986 Infant mortality, childhood nutrition, and ischaemic heart disease in England and Wales. Lancet 327:1077-81

Barker KK. 2005 The Fibromyalgia Story: Medical Authority and Women's Worlds of Pain Philadelphia, PA: Temple Univ. Press

Benezra A 2016 Datafying microbes: malnutrition at the intersection of genomics and global health. BioSocieties 11(3):334-51

Brown P, Morello-Frosch R, Zavestoski S. 2012 Contested Illnesses: Citizens, Science, and Health Social Movements Berkeley: Univ. Calif. Press

Brown P, Zavestoski S, McCormick S, Mayer B, Morello-Frosch R, Gasior Altman R. 2004 Embodied health movements: new approaches to social movements in health. Sociol. Health Illn 26(1):50-80 [PubMed: 15027990]

Buklijas T 2014 Food, growth and time: Elsie Widdowson's and Robert McCance's research into prenatal and early postnatal growth. Stud. Hist. Philos. Biol. Biomed. Sci 47:267-77 [PubMed: 24378592]

Bullard RD. 1993 Anatomy of environmental racism and the environmental justice movement In Confronting Environmental Racism: Voices from the Grassroots, ed. Bullard RD, pp. 15-39. Boston, MA: South End Press

Butler C 2017 A fruitless endeavor: confronting the heteronormativity of environmentalism In Routledge Handbook of Gender and Environment, ed. MacGregor S, pp. 270-84. Abingdon, UK: Routledge

Carson R 1952 Silent Spring New York: Houghton Mifflin

Catton WR Jr., Dunlap RE. 1978 Environmental sociology: a new paradigm. Am. Sociol 13(Feb.):4149

Clarke A, Haraway D. 2018 Making Kin Not Population: Reconceiving Generations Chicago: Prickly Paradigm Press

Colborn T, Vom Saal F, Soto AM. 1993 Developmental effects of endocrine-disrupting chemicals in wildlife and humans. Environ. Health Perspect 101(5):378-84 [PubMed: 8080506]

Colom A 2015 Forced motherhood in Guatemala: an analysis of the Thousand Days Initiative In Privatization and the New Medical Pluralism: Shifting Healthcare Landscapes in Maya Guatemala, ed. Chary A, Rohloff P, pp. 35-50. Lanham, MD: Lexington Books 
Cordner A 2019 Toxic Safety: Flame Retardants, Chemical Controversies, and Environmental Health New York: Columbia Univ. Press

Cortese R, Lu L, Yu Y, Ruden D, Claud EC. 2016 Epigenome-microbiome crosstalk: a potential new paradigm influencing neonatal susceptibility to disease. Epigenetics 11(3):205-15 [PubMed: 26909656]

Crenshaw K 1989 Demarginalizing the intersection of race and sex: a black feminist critique of antidiscrimination doctrine, feminist theory and antiracist politics. Univ. Chicago Leg. Forum 1989:139-67

Crenshaw K 1991 Mapping the margins: intersectionality, identity politics, and violence against women of color. Stanford Law Rev 43:1241-99

Currie J, Zivin JG, Mullins J, Neidell M. 2014 What do we know about short- and long-term effects of early-life exposure to pollution? Annu. Rev. Resour. Econ 6:217-47

Daniels CR. 2006 Exposing Men: The Science and Politics of Male Reproduction New York: Oxford Univ. Press

Davis D-A. 2019 Reproductive Injustice: Racism, Pregnancy, and Premature Birth New York: N. Y. Univ. Press

Davis H, Todd Z. 2017 On the importance of a date, or, decolonizing the Anthropocene. ACME 16(4): 761-80

Dewachi O 2015 Blurred lines: warfare and health care. Med. Anthropol. Theory 2(2):95-101

Di Chiro G 2008 Living environmentalisms: coalition politics, social reproduction, and environmental justice. Environ. Politics 17(2):276-98

Di Renzo GC, Conry JA, Blake J, DeFrancesco MS, DeNicola N, et al. 2015 International Federation of Gynecology and Obstetrics opinion on reproductive health impacts of exposure to toxic environmental chemicals. Int. J. Gynaecol. Obstet 131(3):219-25 [PubMed: 26433469]

Djoudi H, Locatelli B, Vaast C, Asher K, Brockhaus M, Basnett Sijapati B. 2016 Beyond dichotomies: gender and intersecting inequalities in climate change studies. Ambio 45(3):248-62 [PubMed: 27878531]

Dove MR. 2006 Indigenous people and environmental politics. Annu. Rev. Anthropol 35:191-208

Dow K 2016a Making a Good Life: An Ethnography of Nature, Ethics, and Reproduction Princeton, NJ: Princeton Univ. PressBrings reproductive and environmental ethics together in a study of perspectives in small town coastal Scotland about reproduction and the future of human and animal environments.

Dow K 2016b What gets left behind for future generations? Reproduction and the environment in Spey Bay, Scotland. J. R. Anthropol. Inst 22(3):653-69

Dow K, Lamoreaux J. 2019 Reproducing the environment. ReproSoc https:// www.reprosoc.sociology.cam.ac.uk/projects/reproducing-the-envrionment

Eskenazi B, Rosas LG, Marks AR, Bradman A, Harley K, et al. 2008 Pesticide toxicity and the developing brain: pesticides and the developing brain. Basic Clin. Pharmacol. Toxicol 102(2):22836 [PubMed: 18226078]

Fauci AS, Morens DM. 2016 Zika virus in the Americas-yet another arbovirus threat. New Engl. J. Med 374(7):601-4 [PubMed: 26761185]

Fennell C 2016 Are we all Flint? Limn 7 https://limn.it/articles/are-we-all-flint/

Fortun K 2009 Advocacy After Bhopal: Environmentalism, Disaster, New Global Orders Chicago: Univ. Chicago Press

Fortun K 2012 Ethnography in late industrialism. Cult. Anthropol 27(3):446-64

Franasiak JM, Scott RT. 2015 Introduction: microbiome in human reproduction. Fertil. Steril 104(6): 1341-43 [PubMed: 26515381]

Friese C, Marris C. 2014 Making de-extinction mundane? PLOS Biol 12(3):e1001825 [PubMed: 24667704]

Fuentes A, Porter N. 2018 Kinship In Critical Terms for Animal Studies, ed. Gruen L, pp. 182-96. Chicago: Univ. Chicago Press

Gaard G 2010 Reproductive technology, or reproductive justice?: An ecofeminist, environmental justice perspective on the rhetoric of choice. Ethics Environ 15(2):103-29 
Gallo MV, Ravenscroft J, Carpenter DO, Schell LM, Akwesasne Task Force on the Environment. 2018 Persistent organic pollutants as predictors of increased FSH:LH ratio in naturally cycling, reproductive age women. Environ. Res 164:556-64 [PubMed: 29621723]

Gammeltoft TM. 2014 Haunting Images: A Cultural Account of Selective Reproduction in Vietnam Berkeley: Univ. Calif. PressProvides an illuminating study of the intersections of reproductive technologies and environmental and cultural legacies of war.

Gilbert SF. 2014 A holobiont birth narrative: the epigenetic transmission of the human microbiome. Front. Genet 5:282 [PubMed: 25191338]

Ginsburg F, Rapp R. 1991 The politics of reproduction. Annu. Rev. Anthropol 20:311-43 [PubMed: 12288961] This landmark review galvanized study of the politics of reproduction in anthropology in the early 1990 s.

Goldman L, Falk H, Landrigan PJ, Balk SJ, Reigart JR, Etzel RA. 2004 Environmental pediatrics and its impact on government health policy. Pediatrics 113(Suppl. 3):1146-57 [PubMed: 15060212]

Graeter S 2017 To revive an abundant life: Catholic science and neoextractivist politics in Peru's Mantaro Valley. Cult. Anthropol 32(1):117-48

Haraway D 2015 Anthropocene, Capitalocene, Plantationocene, Chthulucene: making kin. Environ. Humanit 6(1):159-65Offers a collection of controversy-confronting critical essays from Kim TallBear, Michelle Murphy, Yu-Ling Huang, Chia-Ling Wu, and Ruha Benjamin with a comprehensive introduction by Adele Clarke.

Heindel JJ, Balbus J, Birnbaum L, Brune-Drisse MN, Grandjean P, et al. 2016 Developmental origins of health and disease: integrating environmental influences. Endocrinology 156:3416-21

Hodgetts T, Grenyer R, Greenhough B, McLeod C, Dwyer A, Lorimer J. 2018 The microbiome and its publics: a participatory approach for engaging publics with the microbiome and its implications for health and hygiene. EMBO Rep 19(6):e45786 [PubMed: 29777052]

Hoke MK, McDade T. 2014 Biosocial inheritance: a framework for the study of the intergenerational transmission of health disparities. Ann. Anthropol. Pract 38(2):187-213

Hoover E 2017 The River Is in Us: Fighting Toxics in a Mohawk Community Minneapolis: Univ. Minn. Press

Hoover E 2018 Environmental reproductive justice: intersections in an American Indian community impacted by environmental contamination. Environ. Sociol 4(1):8-21Presents a definitive statement of the history, character and application of the environmental reproductive justice concept based in a Mohawk community ethnography.

Hoover E, Cook K, Plain R, Sanchez K, Waghiyi V, et al. 2012 Indigenous peoples of North America: environmental exposures and reproductive justice. Environ. Health Perspect 120(12):1645-49 [PubMed: 22899635]

Ivry T 2015 The pregnancy manifesto: notes on how to extract reproduction from the Petri dish. Med. Anthropol 34(3):274-89 [PubMed: 25763460]

Jeffries Hein R 2018 The effects of contemporary political economy on laboratory labor in the production of obesity knowledge and environmental biomedical subjecthood within the sciences of developmental origins of health and disease and epigenetics PhD Diss., Univ. Calif., Los Angel.

Johnson C 2017 Pregnant woman versus mosquito: a feminist epidemiology of Zika virus. J. Int. Political Theory 13(2):233-50

Kaijser A, Kronsell A. 2014 Climate change through the lens of intersectionality. Environ. Politics 23(3):417-33

Kenney M, Müller R. 2017 Of rats and women: narratives of motherhood in environmental epigenetics. BioSocieties 12(1):23-46

Kirksey SE, Helmreich S. 2010 The emergence of multispecies ethnography. Cult. Anthropol 25(4): 545-76

Kowal E, Warin M. 2018 Anthropology, indigeneity, and the epigenome. Am. Anthropol 120(4):82225

Kuehn L, McCormick S. 2017 Heat exposure and maternal health in the face of climate change. Int. J. Environ. Res. Public Health 14(8):e853 [PubMed: 28758917]

Kuzawa C, Sweet E. 2009 Epigenetics and the embodiment of race: developmental origins of US racial disparities in cardiovascular health. Am. J. Hum. Biol 21(1):2-15 [PubMed: 18925573] 
Lamoreaux J 2016 What if the environment is a person? Lineages of epigenetic science in a toxic China. Cult. Anthropol 31(2):188-214

Landecker H 2011 Food as exposure: nutritional epigenetics and the new metabolism. BioSocieties 6(2):167-94 [PubMed: 23227106]

Landecker H, Panofsky A. 2013 From social structure to gene regulation, and back: a critical introduction to environmental epigenetics for sociology. Annu. Rev. Sociol 39:333-57

Landrigan PJ. 2016 Children's environmental health: a brief history. Acad. Pediatr 16(1):1-9 [PubMed: 26498257]

Langwick SA. 2018 A politics of habitability: plants, healing, and sovereignty in a toxic world. Cult. Anthropol 33(3):415-43

Lappé M 2016a Epigenetics, media coverage, and parent responsibilities in the post-genomic era. Curr. Genet. Med. Rep 4(3):92-97 [PubMed: 27867757]

Lappé M 2016b The maternal body as environment in autism science. Soc. Stud. Sci 46(5):675-700 [PubMed: 28948883]

Lappé M, Landecker H. 2015 How the genome got a life span. New Genet. Soc 34(2):152-76 [PubMed: 26213491]

Lappé MD. 2014 Taking care: anticipation, extraction and the politics of temporality in autism science. BioSocieties 9(3):304-28

Larkin B 2013 The politics and poetics of infrastructure. Annu. Rev. Anthropol 42:327-43

Liboiron M 2013 Modern waste as strategy. Lo Squaderno Explor. Space Soc 29:9-12

Liboiron M, Tironi M, Calvillo N. 2018 Toxic politics: acting in a permanently polluted world. Soc. Stud. Sci 48(3):331-49 [PubMed: 29963976]

Little PE. 1999 Environments and environmentalisms in anthropological research: facing a new millennium. Annu. Rev. Anthropol 28:253-84

Lock M 2018 Mutable environments and permeable human bodies. J. R. Anthropol. Inst 24(3):449-74

Lorenzo R 2016 At Standing Rock, environmental justice is reproductive justice. Rewire.News, Sept. 20 https://rewire.news/article/2016/09/20/standing-rock-environmental-justice-reproductivejustice/

Lubitow A 2013 Collaborative frame construction in social movement campaigns: bisphenol-A (BPA) and scientist-activist mobilization. Soc. Mov. Stud 12(4):429-47

Luna Z, Luker K. 2013 Reproductive justice. Annu. Rev. Law Soc. Sci 9:327-52

MacGregor S 2010 'Gender and climate change': from impacts to discourses. J. Indian Ocean Reg $6(2): 223-38$

MacKendrick N 2014 More work for mother: chemical body burdens as a maternal responsibility. Gender Soc 28(5):705-28

MacKendrick N 2018 Better Safe than Sorry: How Consumers Navigate Exposure to Everyday Toxics Oakland: Univ. Calif. Press

MacKendrick N, Cairns K. 2019 The polluted child and maternal responsibility in the US environmental health movement. Signs: J. Women Cult. Soc 44(2):307-32

Mandell R, Israel BA, Schulz AJ. 2018 Breaking free from siloes: intersectionality as a collective action frame to address toxic exposures and reproductive health. Soc. Mov. Stud 18(3):346-63

Mansfield B 2017 Folded futurity: epigenetic plasticity, temporality, and new thresholds of fetal life. Sci. Cult 26(3):355-79

Mansfield B, Guthman J. 2015 Epigenetic life: biological plasticity, abnormality, and new configurations of race and reproduction. Cult. Geogr 22(1):3-20

Masco J 2004 Mutant ecologies: radioactive life in post-Cold War New Mexico. Cult. Anthropol 19(4): $517-50$

Maxwell L 2017 Queer/love/bird extinction: Rachel Carson's Silent Spring as a work of love. Political Theory 45(5):682-704

McCormick S, Brown P, Zavestoski S. 2003 The personal is scientific, the scientific is political: the public paradigm of the environmental breast cancer movement. Sociol. Forum 18(4):545-76 
McDade TW. 2012 Early environments and the ecology of inflammation. PNAS 109(Suppl. 2):1728188 [PubMed: 23045646]

Meloni M, Cromby J, Fitzgerald D, Lloyd S, eds. 2018 The Palgrave Handbook of Biology and Society London: Palgrave Macmillan UK

Moran-Thomas A 2019 Traveling With Sugar: Chronicles of a Global Epidemic Oakland: Univ. Calif. Press

Morello-Frosch R, Pastor M, Sadd J. 2001 Environmental justice and Southern California's "riskscape": the distribution of air toxics exposures and health risks among diverse communities. Urban Aff. Rev 36(4):551-78

Morello-Frosch R, Shenassa ED. 2006 The environmental "riskscape" and social inequality: implications for explaining maternal and child health disparities. Environ. Health Perspect 114(8):1150-53 [PubMed: 16882517]

Muller C, Sampson RJ, Winter AS. 2018 Environmental inequality: the social causes and consequences of lead exposure. Annu. Rev. Sociol 44:263-82

Mulligan CJ. 2016 Early environments, stress, and the epigenetics of human health. Annu. Rev. Anthropol 45:233-49

Murphy M 2011 Distributed reproduction In Corpus, ed. Casper MJ, Currah P, pp. 21-38. New York: Palgrave Macmillan

Murphy M 2013 Distributed reproduction, chemical violence, and latency. Sch. Fem. Online 2013(11.3):1-2

Murphy M 2017a Alterlife and decolonial chemical relations. Cult. Anthropol 32(4):494-503

Murphy M 2017b The Economization of Life Durham, NC/London: Duke Univ. PressPresents a concise historical excavation of the economic logics of family planning and human capital in the twentieth century, refusing population as a term of environmental reproductive justice.

Natl. Res. Counc. 1993 Pesticides in the Diets of Infants and Children Washington, DC: Natl. Acad. Press

Niewöhner J 2011 Epigenetics: embedded bodies and the molecularisation of biography and milieu. BioSocieties 6(3):279-98

Pauly PJ. 1996 How did the effects of alcohol on reproduction become scientifically uninteresting? J. Hist. Biol 29:1-28 [PubMed: 11609217]

Pentecost M 2018 The First Thousand Days: epigenetics in the age of global health See Meloni et al. 2018, pp. 269-94

Petryna A 2002 Life Exposed: Biological Citizens after Chernobyl Princeton, NJ: Princeton Univ. Press

Pollock A 2016 Queering endocrine disruption In Object-Oriented Feminism, ed. Behar K, pp. 18399. Minneapolis: Univ. Minn. Press

Radin J 2017 "Digital natives": how medical and indigenous histories matter for big data. Osiris 32(1): $43-64$

Reagan LJ. 2016 'My daughter was genetically drafted with me': US-Vietnam War veterans, disabilities and gender. Gender Hist 28(3):833-53

Richardson CT. 2006 Environmental justice campaigns provide fertile ground for joint efforts with reproductive rights advocates. Guttmacher Policy Rev 9(1):14-17

Richardson S 2015 Maternal bodies in the postgenomic order: gender and the explanatory landscape of epigenetics In Postgenomics: Perspectives on Biology after the Genome, ed. Richardson S, Stavens H, pp. 210-31. Durham, NC: Duke Univ. Press

Roberts EFS. 2015 Food is love: And so, what then? BioSocieties 10(2):247-52

Roberts EFS. 2016 When nature/culture implodes: feminist anthropology and biotechnology In Mapping Feminist Anthropology in the Twenty-First Century, ed. Lewin E, Silverstein LM, pp. 105-25. New Brunswick, NJ: Rutgers Univ. Press

Roberts EFS. 2017 What gets inside: violent entanglements and toxic boundaries in Mexico City. Cult. Anthropol 32(4):592-619

Roberts EFS, Sanz C. 2018 Bioethnography: a how-to guide for the twenty-first century See Meloni et al. 2018, pp. 749-75 
Ross LJ, Solinger R. 2017 Reproductive Justice: An Introduction Oakland, CA: Univ. Calif. Press

Sasser JS. 2018 On Infertile Ground: Population Control and Women's Rights in the Era of Climate Change New York: N. Y. Univ. PressPresents a study of resurgent population control narratives linked to climate crisis in contemporary international development and the framing of women as "sexual stewards" of the environment.

Sayre NF. 2012 The politics of the Anthropogenic. Annu. Rev. Anthropol 41:57-70

Schiavenato S, Rapp R. 2018 Enduring innovation in reproduction. BioSocieties 13(2):536-55

Shapiro N, Zakariya N, Roberts J. 2017 A wary alliance: from enumerating the environment to inviting apprehension. Engag. Sci. Technol. Soc 3:575-602

Sharp GC, Lawlor DA, Richardson SS. 2018 It's the mother!: How assumptions about the causal primacy of maternal effects influence research on the developmental origins of health and disease. Soc. Sci. Med 213:20-27 [PubMed: 30055422] [**AU: This reference is not cited in the text. Please add there or remove from here.**]now cited.

Shostak S 2013 Exposed Science: Genes, the Environment, and the Politics of Population Health Berkeley: Univ. Calif. Press

Singer M 2016 Anthropocentrism and the making of environmental health In Routledge Handbook of Environmental Anthropology, ed. Kopnina H, Shoreman-Ouimet E. New York: Routledge

Suryanarayanan S, Kleinman DL. 2016 Vanishing Bees: Science, Politics, and Honeybee Health New Brunswick, NJ: Rutgers Univ. Press

Sze J 2006 Noxious New York: The Racial Politics of Urban Health and Environmental Justice Cambridge, MA: MIT Press

TallBear K 2011 Why interspecies thinking needs indigenous standpoints. Hum. Is More than Hum. Ser. Fieldsights, Nov. 18 https://culanth.org/fieldsights/260-why-interspecies-thinking-needsindigenous-standpoints

Taussig K-S, Hoeyer K, Helmreich S. 2013 The anthropology of potentiality in biomedicine. Curr. Anthropol 54(S7):S3-14

Taylor DE. 2000 The rise of the environmental justice paradigm: injustice framing and the social construction of environmental discourses. Am. Behav. Sci 43(4):508-80

Terry G 2009 No climate justice without gender justice: an overview of the issues. Gender Dev 17(1): $5-18$

Thayer ZM, Non AL. 2015 Anthropology meets epigenetics: current and future directions. Am. Anthropol 117(4):722-35

Valdez N 2018 The redistribution of reproductive responsibility: on the epigenetics of "environment" in prenatal interventions. Med. Anthropol. Q 32(3):425-42 [PubMed: 29392771]

Vineis P, Chan Q, Khan A. 2011 Climate change impacts on water salinity and health. J. Epidemiol. Glob. Health 1(1):5-10 [PubMed: 23856370]

Voland E 1998 Evolutionary ecology of human reproduction. Annu. Rev. Anthropol 27:347-74 [PubMed: 12295433]

Waggoner MR. 2017 The Zero Trimester: Pre-Pregnancy Care and the Politics of Reproductive Risk Oakland: Univ. Calif. Press

Wahlberg A 2018 Good Quality: The Routinization of Sperm Banking in China Oakland: Univ. Calif. Press

Warin M, Zivkovic T, Moore V, Davies M. 2012 Mothers as smoking guns: fetal overnutrition and the reproduction of obesity. Fem. Psychol 22(3):360-75

Washburn R 2014 Measuring personal chemical exposures through biomonitoring: the experiences of research participants. Qual. Health Res 24(3):329-44 [PubMed: 24549408]

WHO (World Health Organiz.). 2017 Don't Pollute My Future! The Impact of the Environment on Children's Health. Geneva: WHO https://www.who.int/ceh/publications/don-t-pollute-myfuture/en/

Whyte KP. 2016 Is it colonial déjà vu? Indigenous peoples and climate injustice In Humanities for the Environment: Integrating Knowledge, Forging New Constellations of Practice, ed. Adamson J, Davis M, pp. 88-104. London/New York: Earthscan/Routledge 
Wilson NJ, Inkster J. 2018 Respecting water: indigenous water governance, ontologies, and the politics of kinship on the ground. Environ. Plan. E Nat. Space 1(4):516-38

Wylie S, Shapiro N, Liboiron M. 2017 Making and doing politics through grassroots scientific research on the energy and petrochemical industries. Engag. Sci. Technol. Soc 3:393-425

Yates-Doerr E 2015 The Weight of Obesity: Hunger and Global Health in Postwar Guatemala Oakland: Univ. Calif. Press

Yates-Doerr E 2019 Whose global, which health? unsettling collaboration through careful equivocation. Am. Anthropol 121(2):297-310 [PubMed: 31130735]

\section{RELATED RESOURCES}

Children's Environmental Health Network. https://cehn.org/our-work/research/research-publications/

Climate Change and Reproductive Justice. http://www.populationconnection.org/climate-repro-justice/ MADRES Environmental Health Disparities Center. https://envhealthcenters.usc.edu/category/madres

Reproductive Sociology Research Group, Cambridge University. https://

www.reprosoc.sociology.cam.ac.uk/ 